\title{
ФОРМУВАННЯ ЦІЛІСНОГО СВІТОГЛЯДУ МАЙБУТНІХ УЧИТЕЛІВ ЗАРУБІЖНОЇ ЛІТЕРАТУРИ ЗАСОБАМИ ІСТОРИКО-ЛІТЕРАТУРОЗНАВЧИХ ДИСЦИПЛІН
}

Дороніна Т. О. Формування цілісного світогляду майбутніх учителів зарубіжної літератури засобами історико-літературознавчих дисциплін.

У статті розглянуто проблеми викладання історії зарубіжної літератури у вищих навчальних закладах України, проаналізовано можливості формування цілісної картини світу майбутніх учителів зарубіжної літератури засобами історико-літературознавчах дисциплін та актуалізовано використання синхронічного методу як одного із засобів формування цілісного світогляду сучасних студентів - майбутніх учителів зарубіжної літератури.

Ключові слова: вища школа, освіта, світова література, синхронічний метод, учитель зарубіжної літератури.

Доронина Т. А. Формирование целостного мировоззрения будущих учителей зарубежной литературы средствами историко-литературоведческих дисциплин.

В статье рассмотрены проблемы преподавания истории зарубежной литературы в высших учебных заведениях Украины, проанализированы возможности формирования целостной картины мира будущих учителей зарубежной литературы средствами историко-литературоведческих дисциплин, актуализировано использование синхронического метода как одного из средств формирования целостного мировоззрения современных студентов - будущих учителей зарубежной литературы.

Ключевые слова: высшая школа, образование, мировая литература, синхронический метод, учитель зарубежной литературы.

Doronina T.A. Forming of a complete worldview of future teachers of foreign literature by means of historical and literary disciplines.

The article is devoted to the problems of teaching the history of foreign literature in higher educational establishment of Ukraine, the possibility of forming of a complete picture of the world of future teachers of foreign literature by means of historical and literary disciplines is analyzed, using of the synchronic method as a mean of forming of a complete worldview of modern students - future teachers of foreign literature is actualized.

Key words: higher establishment, education, world literature, synchronic method, a teacher of foreign literature.

Нині відбувається побудова нової парадигми вищої освіти, що зумовлено загальним процесом євроінтеграції, який був проголошений Україною пріоритетним напрямом державобудування. Приєднання до Болонського процесу (перехід до ступеневої освіти із суттєвим реформуванням іï змісту та обсягу) актуалізує питання якості освіти та конкурентоспроможності нинішнього випускника вищого навчального закладу. Оновлення процесу освіти у вищому навчальному закладі унормовано в низці законодавчих документів (Закони України «Про освіту», «Про вищу освіту», Національна доктрина розвитку освіти), у яких актуалізовано головні завдання вітчизняної освіти як соціального інституту. Відтак розвиток вітчизняної системи вищої педагогічної освіти висуває нові вимоги до професійного рівня випускників, які повинні володіти високим фаховим (науковим та методичним) рівнем, сучасним світоглядом, бути готовими до використання вже здобутих психолого-педагогічних знань та засвоєння нової інформації, уміти працювати за новою (суб'єкт-суб'єктною) системою подання інформації та організації навчально-виховного процесу.

Проблема змісту та організації освіти, ऑii якості, професійних компетенцій та особистісних якостей майбутніх учителів, а отже, сучасного вчительства широко 
представлена в працях вітчизняних та зарубіжних науковців (В. Адольф, А. Алексюк, В. Андрущенко, С. Архангельский, Ю. Бабанський. Я. Болюбаш, Ю. Варданян, О. Глузман, В. Гузєєв, М. Свтух, І. Зязюн, В. Лозова, І. Підласий, О. Савченко, Г. Селевко, В. Сластьонін, А. Щербаков, М. Ярмаченко та ін.). Комплекс вимог до сучасного вчителя неможливо перерахувати, він постійно оновлюється, розширюється відповідно до соціокультурного континууму. Донедавна традиційна освіта обмежувалася знаннєвопросвітницькою моделлю, нині вона модернізована в компетентністу модель. Проте науковці дискутують, чи сприяють ці процеси формуванню цілісної картини світу майбутніх учителів, оскільки відчутний фрагментарний характер світогляду випускників (кліпове мислення / свідомість, втрата текстоцентричної культури - об'єктивні чинники сучасної молодіжної культури, - згідно з думкою К. Фрумкіна [10]).

Слід наголосити, що власне в освітньому дискурсі поняття «картина світу» знайшло обгрунтування в науковому доробку вітчизняних та зарубіжних дослідників (М. Блох, Г. Голіцин, Г. Колшанський, Т. Кузнецова, Л. Лебедєва, Г. Матвєєв, Т. Шутунова та ін.). Однак, науковці констатують, що нині світоглядна функція навчального процесу в кращому випадку обмежується становленням часткових картин світу - фізичної, економічної, біологічної та ін., отже, їхнє інтегрування не відбувається. Тому перед освітніми працівниками постало питання пошуку нових форм і методів організації та здійснення ефективного навчання, яке б грунтувалося на історико-культурних та духовноморальних традиціях та корелювалося із провідними тенденціями розвитку європейської освіти. Відтак, низка локальних питань щодо створення світоглядної цілісної картини у студента-філолога, майбутнього вчителя світової літератури, лишилася поза увагою науковців. I причин тут кілька: відсутність єдиного освітнього стандарту зі світової літератури для студента-філолога; панування традиційної історико-хронологічної періодизації навчального (літературного) матеріалу; недостатня увага методистів до особливостей вивчення саме світової літератури у вищому навчальному закладі тощо. До проблем, пов'язаних із якістю літературної освіти, можемо віднести відсутність у студентів достатніх та грунтовних історичних знань, без яких неможливе якісне вивчення розвитку літературного процесу. Усі ці складності породжують суперечність між державними вимогами до кваліфікаційно-освітнього рівня випускника (вчителя світової літератури) та фрагментарністю історико-літературних знань, здобутих під час вивчення літературознавчих дисциплін (зокрема - «Історії російської літератури»).

Необхідність розв'язання виявленої суперечності зумовила мету статmi встановлення можливостей формування цілісної картини світу у світогляді майбутніх учителів зарубіжної літератури засобами історико-літературознавчих дисциплін.

Передовсім слід відзначити певну неузгодженість у визначенні того, як саме формується кваліфікаційний рівень учителя зарубіжної (нині - світової) літератури. Очевидно, що цю кваліфікацію студенти отримують у педагогічних інститутах / університетах на філологічних факультетах. Проте існує певна суперечність у спрямованості та змісті цієї кваліфікації: оскільки викладачами світової літератури працюють і вчителі української мови та літератури, і вчителі російської мови і літератури, таку ж кваліфікацію здобувають випускники факультетів іноземних мов (педагогічних інститутів/ університетів), то виникає питання - які саме фахові дисципліни (окрім очевидної методики викладання літератури) вивчають ці студенти, та хто і як унормовує зміст цих дисциплін (оскільки в залікових книжках та навчальних планах подається в кращому випадку одне формулювання - «Історія зарубіжної літератури»). Відповідь не така очевидна, як здається. Залишається нерозв'язаним питання щодо місця «Історії російської літератури» в літературознавчій підготовці філологів. Окремо ця дисципліна вивчається лише студентами - майбутніми вчителями російської мови, до курсу «Історії зарубіжної літератури» на інших спеціальностях вона не входить, а в шкільному курсі «Світової літератури» питання творчості російських письменників передбачено. Проте це питання можливо вирішити, якщо запропонувати навчальним відділам відповідних вишів 
увести до навчальних планів, скажімо, спецкурс - «Історія російської літератури в шкільному курсі світової літератури».

Наступне питання, яке також стосується якості освіти, що здобувають майбутні вчителі зарубіжної літератури, - віднесення до їхньої освіти історичного чинника, який, на нашу думку, недостатньо представлений у фаховій підготовці студентів-філологів. Звернення до наукових публікацій щодо зазначеного питання дозволяє виокремити найбільш обговорювані серед методистів-істориків теми: зміст та місце «Історії» серед інших навчальних дисциплін; методичні особливості висвітлення контроверсійних тем; дидактичні умови ефективного проведення занять тощо. Серед питань, які хвилюють дослідників, найбільш актуальним залишається оновлення змісту дисципліни, оскільки нині відбувається дублювання змісту шкільного курсу історії. Це, на думку В. Проценко, «призводить до «розрихлення» історичної свідомості студентів, що зумовлює втрату в них інтересу до вивчення дисципліни», хоча саме у вивченні історії вбачається шлях до «підвищення політичної культури широких кіл населення» [7, с. 90]. Цілком слушну думку автора можемо лише підсилити тим, що саме історичні знання є запорукою формування загальної культури студентства загалом та безумовним підгрунтям побудови в їх свідомості цілісної картини світу.

Поняття «картина світу» нині набуло свого поширення в низці природничих та гуманітарних наук. Свій початок ця дефініція бере 3 природничого наукового дискурсу, коли в середині XX ст. (із розвитком фізики, математики, біології) було проблематизовано питання можливості наукової побудови цілісної картини світу. Відтак саме в середині XX століття відбулася значна перебудова власне наукового знання. «Якщо у XIX столітті картина світу трактувалася як філософсько-світоглядна побудова, то для ХХ століття, особливо його другої половини, це науково-філософська система уявлень про загальні властивості та закономірності світу (природи та соціального середовища)» [4]. Отже, як зазначає автор цитованого фрагменту Т. Кузнецова, у науковій перспективі поняття «картина світу» спрямовано «на узагальнене уявлення про світ чи на певну загальну онтологію та світогляд, наукове не лише тому, що відпрацьовувалося науковою філософією, але й тому, що воно відпрацьовано всією сукупністю наук» [4]. Отже, у сучасній науці представлено таку дефініцію поняття «картина світу» - «багатовимірний та складний за структурою феномен, який відображає цілісне уявлення людини про світ та своє місце в ньому» [6, с. 124]. I у створенні цього цілісного уявлення значення літератури (зокрема історії літератури) неможливо переоцінити.

Серед проблем вивчення історії літератури чільне місце посідає еволюція художньої творчості людини як засіб їі самореалізації та самоусвідомлення, відтворення та створення всесвіту, як засобу розвитку світогляду та світорозуміння. Світогляд - філософська категорія, яка $\epsilon$ «системою поглядів на об'єктивний світ та місце в ньому людини, на ставлення людини до навколишнього середовища та до себе, а також зумовлені цими поглядами головні життєві позиції людей, їхні переконання, ідеали, принципи пізнання та діяльності, ціннісні орієнтації» [9, с. 375]. Отже, саме література (історія іiі розвитку) безпосередньо демонструє генезу світогляду людства, усвідомлення цього процесу неможливе з відривом від історичного контексту.

Практика багаторічної роботи у студентський аудиторії з викладання курсу «Історії російської літератури» переконує у вкрай недостатній історичній підготовці студентівфілологів, що надзвичайно ускладнює навчальний процес та загрожує його перетворенням в оповідання фактів біографії письменників та переказ літературних творів. Із першого курсу студентам-філологам говорять про існування трьох головних складників літературознавства: теорія літератури, історія літератури та літературна критика. Уже на п’ятій сторінці вітчизняного підручника 3 теорії літератури за науковою редакцією О. Галича наголошено: «Твори художньої літератури - це завжди частина культурної спадщини певного народу. Написані в конкретно-історичних умовах доби, вони $\epsilon$ частиною історичної пам'яті цього народу. Наука про літературу не може не враховувати 
міцний взаємозв'язок художньої творчості з розвитком окремного народу. У такому розумінні літературознавство постає як історична наукова дисципліна, що допомагає icmopiї вивчати суспільне буття певного народу» [1, с. 5]. Курсивне виділення в цитованому фрагменті зроблено нами навмисно задля акцентування сучасної точки зору щодо значущості зв'язку між історією та літературознавством. Утім, і в минулому філологічної освіти було саме таке розуміння. Свідченням необхідності поєднання історичних, літературознавчих та лінгвістичних знань слугує історичний досвід існування 31850 p. у ряді університетів Російської імперії історико-філологічних факультетів. Тут викладали філософію, класичну філологію, російську словесність, слов'янську філологію, загальну та російську історію, романо-германську філологію, історію церкви, теорію та історію мистецтв. Про результат такої освіти виразно свідчать $\dddot{1}$ здобувачі. Випускниками історико-філологічного факультету Санкт-Петербурзького університету були І. Анненський, Ф. Батюшков, О. Блок, Вс. Іванов, Д. Мережковський, М. Фасмер, І. Цвєтаєв, М. Чернишевський, Л. Щерба та ще багато інших видатних особистостей. У дореволюційну добу на історико-філологічному факультеті Новоросійського (пізніше - Одеського) університету працювали видатні діячі вітчизняної філології - В. Григорович, Д. Овсянико-Куликовський, В. Істрін, П. Біціллі, Б. Ляпунов, О. Томсон, П. Потапов. Проте, у радянські часи, у 1919 р. постановою Наркомпросу історико-філологічні факультеті було замінено факультетами суспільних чи суспільногуманітарних наук. Наступного (1920р.) року ліквідовано й університети, їх перетворили на інститути народної освіти, перед якими постало завдання «давати масову підготовку в точній відповідності з вимогами сучасного життя. Для цього вона повинна поділятися на функціональні факультети (наприклад, «педагогічний» факультет, а не «математичний» тощо), курс яких ... повинен бути підібраний виключно з точки зору підготовки до цієї функції і скорочений наскільки можливо (майже для всіх факультетів до 3-х років)» [2, c. 96]. Поступово головною метою вищої освіти стало виконання партійних рішень, саме iз 20-х років XX століття перед вищою школою постала мета «політичного захоплення вищої школи», а саме: «1) забезпечення революційного спрямування роботи ВНЗ; 2) політичне виховання всіх студентів, хто проходив школу; 3) використання ВНЗ для підготовки якомога більшої кількості спеціалістів, що вийшли з пролетаріату» [5]. Що відбувалося насправді? І що відбувається тепер?

Історія як наукова та навчальна дисципліна, що спрямована на формування світогляду людини, була відірвана від літератури за ідеологічними мотивами. Уже на початку 20$\mathrm{x}$ років XX ст. «органи радянської влади впритул підійшли до якісної перебудови системи навчання суспільних наук» [3], тому соціальні науки (філософія, історія) були зорієнтовані виключно на формування молоді на комуністичних засадах, будь-яке вільне мислення було неприпустимим. Ця тенденція відчутна і нині, коли історія залишається відірваною від інших гуманітарних дисциплін, зокрема літератури. І справа не в тому, що історія - це самостійна наука (це факт доведений), а в тому, що відокремлення цих дисциплін призвело до порушення онтологічних зв'язків світогляду, картини світу.

Історія літератури як навчальна дисципліна стала викладатися як історія творчого доробку окремих авторів, що унаочнюють підручники з літератури (особливо шкільні), де переважає монографічне висвітлення навчальних тем. Хоча в навчальних програмах 3 історії літератури (зокрема російської) зберігається історична періодизація літературного розвитку, проте що це за «періодизація». Якщо навчальні курси 3 історії зарубіжної / світової літератури умовно поділяють на періоди відповідно до змін естетичної картини світу (Відродження, Просвітництво) чи за хронологічним (література першої / другої половині XIX століття) принципом, у періодизації «Історії російської літератури» до цих пір зберігається «поділ» відповідно до етапів розвитку визвольного руху: 1/3 XIX століття (декабристське повстання); 2/3 XIX століття (питання відміни кріпацтва); 3/3 XIX століття (підготовка майбутньої революції, цікаво, що верхня межа цього періоду припадала на час створення марксистських гуртків) і взагалі малозрозуміле 
виокремлення літератури кінця XIX - початку XX століть, яке закінчувалося (?) 1917 роком. Такий підхід не лише не сприяв формуванню цілісності світогляду, а навпаки його розшаровував, оскільки творча біографія письменника не може бути точно вписана в чіткі хронологічні межі (скажімо, творчість Л. Толстого вивчається у третьому періоді XIX століття, поряд із творчим доробком Ф. Достоєвського та А. Чехова, хоча Ф. Достоєвський починав свою творчість ще в 50-х роках XIX століття, як і Л. Толстой, який поряд із А. Чеховим плідно працював і на початку століття XX-го). Цей традиційний поділ за відсутності історичного (знаннєвого) підгрунтя створює умови, коли брак уяви про одночасну роботу тих чи тих письменників призводить до плутанини в поглядах студентів, збіднення їх світогляду уявою про літературний процес як поступову зміну творчих фігур на літературних теренах. Традиційний діахронічний метод вже не може сповна компенсувати «історичні» втрати, оскільки хронологічно-послідовне висвітлення матеріалу (поява, розвиток) певним чином обмежує уявлення студентів про неоднозначність, суперечливість та багатоаспектність розвитку літератури.

Відтворення цілісної картини світу сучасного вчителя зарубіжної літератури, на нашу думку, можливе із використанням синхронічного підходу.

Синхронічний метод (поряд із описовим, порівняльно-історичним, ретроспективним, хронологічним) широко використовується в історії та дозволяє вивчати події і явища, які відбувалися одночасно в різних народах та в різних країнах. У навчально-методичних джерелах 3 історії підкреслюється статичність цього методу та пропонується його використання одночасно із хронологічним, що сприятиме проблемно-пошуковому навчанню, для чого складаються синхронічні таблиці, у стовпчиках яких і вписуються необхідні дані. Один із варіантів такої роботи представлено в окремому виданні «Синхронистическая таблица IX- XX вв. Россия-Запад-Восток» [8]. Упорядники цього видання зокрема мотивують використання синхронічних таблиць у навчальному процесі необхідністю формування в учнів масштабного історичного бачення та творчих здібностей щодо осмислення історичного досвіду людства, можливістю поєднання різноманітних історичних фактів у загальній картині історії людства та цитують дуже слушну думку Л. Гумільова про те, що «мета звичайної хронологічної таблиці нагадування», а «синхроністичної - запам’ятовування» $[8$, с. 4].

Керуючись наведеними вище мотивами, ми також використовуємо аналогічні таблиці у вивченні курсу «Історія російської літератури». Головна мета використання синхронічного методу під час вивчення історії літератури - зіставлення літературних явищ із суспільно-політичними процесами та мистецькими подіями. Таблиця поділена на чотири секції: дата, суспільно-політичні факти, явища літературного життя, культурномистецькі події. Студенти працюють над укладанням цих таблиць упродовж усього курсу вивчення історії літератури та мають можливість постійно їі доповнювати. Так поступово iз фрагментарних даних складається цілісна картина розвитку літературного процесу на тлі соціокультурного розвитку.

Узагальнюючи розгляд проблем вивчення історії зарубіжної літератури студентамифілологами, слід наголосити, що створення цілісного світогляду майбутніх учителів можливе лише за умови поєднання у процесі вивчення «Історії зарубіжної літератури» фактів історико-культурного характеру. Одним із засобів такого поєднання $\epsilon$ використання синхронічного методу. Переконані, що синхронічний метод не лише дає можливість одночасного розгляду літературних, мистецьких та соціальних явищ, а сприяє багатоаспектному погляду на історико-культурний розвиток суспільства, що дозволяє відтворити панорамне бачення літературного явища, усвідомити одночасний розвиток творчості окремих митців, відтворює цілісність та масштабність картини світу.

\section{Література}

1. Галич О. Теорія літератури : [підруч. для студентів філолог. спец. ] / Галич О., Назарець В., Васильєв С.; за наук. ред. О. Галича. - К. : Либідь, 2001. - 488 с. 2. Директивы ВКП(б) по вопросам просвещения : вопросы народного просвещения в основных директивах съездов, 
конференций, совещаний и ЦК ВКП(б). - М.; Л. : НКПрос РСФСР : Государственное издательство, 1929. - 111 с. З. Козлова Л. А. Институт красной профессуры (1921-1938) / Л. А. Козлова // Социологический журнал. - 1997. - № 4. - С. 209-220. 4. Кузнецова Т. Ф. Картина мира / Т. Ф. Кузнецова. - [Электронный ресурс]: Информационный гуманитарный портал «Знание. Понимание. Умение». - 2008. - №4 - (Серия : «Культурология»). - Режим доступа: http://www.zpu-journal.ru/e-zpu/2008/4/Kuznetsova/. 5. Лагно А. Р. Институт ректорства в Московском университете 1920-х - 1930-х гг. / А. Р. Лагно - [Электронный ресурс]: Государственное управление. Электронный вестник. - 2011. - № 29. - Режим доступа: http://ejournal.spa.msu.ru/images/File/2011/29/Lagno.pdf. 6. Первушина О. В. Картина мира: возможность феноменологического похода / О. В. Первушина // Мир науки, культуры, образования. - 2009. - № 5 (17). - С. 123-126. 7. Проценко В. О. До проблеми викладання гуманітарних дисциплін у технічному ВНЗ / В. О. Проценко // Вісник ЛНУ імені Тараса Шевченка. - 2012. - № 10 (245). С. 88-95. 8. Синхронистическая таблица IX-XX вв. Россия-Запад-Восток / А. Т. Степанищев, Д. Н. Филиповых. - М. : Гуманитар. изд. центр ВЛАДОС, 2007. - 512 с. 9. Философский энциклопедический словарь [состав. Л.Ф. Ильичев и др.]. - М. : Советская энциклопедия, 1983. 840 с. 10. Фрумкин К. Клиповое мышление и судьба линейного текста // [Электронный ресурс] / К. Фрумкин. - Ineternum. - 2010. - № 1. - Режим доступа: http://nounivers.narod.ru/pub/kf_clip.htm.

УДК 378.14

I. П. Дроздова,

доктор педагогічних наук, доиент, Харківський національний автомобільно-дорожній університет

\section{СЕМІНАРСЬКІ ТА ПРАКТИЧНІ ЗАНЯТТЯ ДЛЯ РОЗВИТКУ КРЕАТИВНИХ УМІНЬ СТУДЕНТІВ ІЗ ПРОФЕСІЙНОГО МОВЛЕННЯ ЗА ФАХОМ}

Дроздова І. П. Семінарські та практичні заняття для розвитку креативних умінь студентів із професійного мовлення за фахом.

У статті проаналізовано специфіку семінарських і практичних занять із метою розвитку креативних умінь студентів із професійного мовлення за фахом, визначено і запропоновано приклади моделей семінарського і практичного занять як ефективних організаційних форм роботи у вищій школі.

Ключові слова: семінарські та практичні заняття, професійне мовлення, види створюваних комунікативних ситуацій, засоби контролю, матеріальне забезпечення.

Дроздова И. П. Семинарские и практические занятия для развития креативных умений студентов в профессиональной речи по специальности.

В статье проанализировано специфику семинарских и практических занятий с целью развития креативных умений студентов в профессиональной речи по специальности, определено и предложено примеры моделей семинарского и практического занятий как эффективных организационных форм работы в высшей школе.

Ключевые слова: семинарские и практические занятия, профессиональная речь, виды создаваемых коммуникативных ситуаций, способы контроля, материальное обеспечения.

Drozdova I. P. Seminars and workshops for development of creative abilities of Students of nonphilological profile concerning professional communication on specialty.

The paper analyzes the specifics of seminars and workshops with the aim of developing creative skills of students concerning professional communication on specialty is determined, and examples of models of seminars and workshops as effective organizational forms of work in high school are offered.

Key words: seminars and workshops, professional communication of students, types of created communicative situations, control methods, material supply.

Важливими формами організації навчальної діяльності студентів-нефілологів у ВНЗ з метою розвитку їхнього професійного мовлення є семінарські та практичні заняття. Як і лекції, вони мають свій план проведення залежно від мети заняття та дидактичних комунікативних цілей. У системі ВНЗ на нефілологічних факультетах такі заняття повинні формувати креативні вміння студентів із професійного мовлення за фахом. 